\title{
Kondisi makroekonomi dan kinerja perbankan di Indonesia
}

\author{
Irma Febriana Mk*; Nurbetty Herlina Sitorus; Rizka Malia
}

Fakultas Ekonomi dan Bisnis, Universitas Lampung, Lampung

*E-mail korespodensi:irmaf_mk@yahoo.co.id

\begin{abstract}
The purpose of this study was to see how the long-term and short-term relationship between banking performance and macroeconomic variables. The analysis method used is the vector error correction model (VECM) with the variables ROA, BOPO, LDR, industrial production index, CPI, and BI rate. The results of this study indicate that there is a significant positive relationship between ROA and industrial production index in the long run and a significant negative relationship between ROA and CPI in the long and short term. There is a significant negative relationship between BOPO and the industrial production index in the long and short term. LDR has a significant negative relationship with all macro variables in the long term whereas, in the short term, LDR has a significant negative relationship with the CPI.
\end{abstract}

Keywords: Banking performance, Macroeconomic, Vector error correction models

\begin{abstract}
Abstrak
Tujuan penelitian ini untuk melihat bagaimana hubungan jangka panjang dan jangka pendek antara kinerja perbankan dengan variabel makroekonomi. Metode analisis yang digunakan adalah vector error correction model (VECM) dengan variabel ROA, $\mathrm{BOPO}, \mathrm{LDR}$, industrial production index, IHK, dan BI rate. Hasil penelitian ini menunjukkan bahwa adanya hubungan postif signifikan antara ROA terhadap industrial production index dalam jangka panjang dan adanya hubungan negatif signifikan antara ROA terhadap IHK dalam jangka panjang dan jangka pendek. Adanya hubungan negatif signifikan antara BOPO dengan industrial production index terhadap jangka panjang dan jangka pendek. LDR mempunyai phubungan negatif signifikan dengan semua variabel makro pada jangka panjang sedangkan, pada jangka pendek LDR mempunyai hubungan negatif signifikan dengan IHK.
\end{abstract}

Kata kunci: Kinerja perbankan, Makroekonomi, Vector error correction models

\section{PENDAHULUAN}

Menurut pendapat Miskin, (2008) menyatakan bahwa bank merupakan sumber utama bagi pembiayaan eksternal dalam suatu bisnis di semua Negara. Bahkan perannya lebih besar lagi di Negara-negara berkembang, tidak terkecuali di Indonesia. Fungsi bank sebagai intermediary institution memiliki peran strategis bagi engembangan perekonomian suatu negara. Kinerja bank yang baik secara individual maupun secara system diharapkan dapat meningkatkan kontribusinya dalam perekonomian. Peran bank yang begitu besar, dan penting untuk memastikan bahwa sistem keuangan dalam perekonomian di suatu negara juga berjalan dengan lancer dan efisien. Kinerja bank dapat dipengaruhi oleh factor internal maupun eksternal, factor internal yang dimaksud dapat berupa daya saing masing-masing bank, sedangkan factor eksternal dapat berupa kondisi makro dan keuangan suatu negara secara umum. 
Kondisi makro yang kondusif dapat memberikan lingkungan keuangan yang positif terhadap perkembangan perbankan itu sendiri. Sebaliknya, kondisi makro dan keuangan yang kurang stabil dapat mempengaruhi resiko pasar dan resiko kredit perbankan yang gilirannya dapat berdampak pada kinerja perbankan. Layaknya suatu sistem, stabilitas sistem perbankan merupakan unsur terciptanya stabilitas sistem keuangan dan bermuara kembali pada stabilitas perekonomian suatu negara (Gizycki, 2001).

Berdasarkan uraian diatas, penulis tertarik untuk membahas mengenai hubungan jangka panjang dan jangka pendek antara variabel kinerja keuangan dengan variabel makroekonomi, respon kinerja perbankan akibat adanya shock atau guncangan yang terjadi pada variabel makroekonomi, serta melihat kontribusi terbesar dari variabel makro dalam perhitungan kinerja perbankan. Sehingga menjadi penting dilakukan Penelitian "Kondisi makroekonomi dan kinerja perbankan di Indonesia"

\section{METODE}

\section{Metode penelitian}

Metode yang digunakan dalam penelitian ini adalah metode Vector Error Correction Models (VECM) dengan disertai Impulse Response Function (IRF) dan Variance Decomposition (VD) untuk melihat hubungan antara variabel bebas dan terikat, respon variabel kinerja keuangan akibat shock yang terjadi pada variabel makrorkonomi, dan yang terakhir untuk melihat kontribusi terbesar dari variber makro ekonomi terhadap varaibel kinerja perbankan.

Analisis data yang dilakukan yaitu dengan pendekatan kuantitatif deskriptif. Kuantitatif merupakan metode penelitian yang berlandaskan pada positivism, digunakan untuk melihat sampel tertentu Soegiyono (2012). Kuantitatif banyak menuntut penggunaan angka, dari mulai pengumpulan data, penafsiran terhadap data tersebut, serta penampilan dari hasilnya. Sedangkan deskriptif merupakan metode yang bertujuan mendeskripsikan atau memberikan gambaran terhadap suatu objek penelitian yang diteliti melalui sampel dan umum. Pendekatan deskriptif dilakukan dengan melihat pergerakan variabel secara grafis dan meninjau kejadian-kejadian dibalik pergerakannya.

Data yang digunakan dalam penelitian ini yaitu data variabel makroekonomi (IPI, IHK, dan BI rate) yang diperoleh dari website resmi BPS dan BI. Sedangkan variabel kinerja yang digunakan yaitu (ROA, BOPO, dan LDR) yang diperoleh dari website resmi BI dan OJK. Data yang digunakan data time series periode 2010 sampai 2018.

\section{Model analisis}

Analisis VAR dapat dikaitkan sebagai alat analisis yang sangat berguna, baik dalam memahami adanya hubungan timbal balik antara variabel ekonomi maupun dalam pembentukan model ekonomi yang berstruktur. Model VAR menganggap bahwa semua variabel ekonomi adalah saling tergantung dengan yang lain (Widarjono, 2016).

$$
Y_{n t}=\alpha+\beta_{i n} Y_{1 t-i}+\alpha_{i n} Y_{2 t-i}+\cdots+n_{i n} Y_{n t-i}+e_{n t}
$$

Dimana :

$\mathrm{Y}_{\mathrm{nt}}=$ Elemen vektor variabel

$\mathrm{Y}_{1 \mathrm{t}-\mathrm{i}}=$ Elemen variabel endogen pada tahun sebelumnya

$\beta_{0}=$ Konstanta

$\beta_{\mathrm{in}}, \alpha_{\mathrm{in}, \ldots . .} \mathrm{n}_{\text {in }}=$ Koefisien variabel endogen

$\mathrm{e}_{\mathrm{nt}}=$ Error term

Penelitian ini menggunakan keragka model VAR untuk mengetahui bagaimana 
kondisi makroekonomi dengan variabel kinerja perbankan yang tercermin (ROA, BOPO, LDR). Struktur model ini dimulai dengan 1). Hubungan dari kondisi IPI, IHK dan BI rate dengan kinerja perbankan. 2) Respon ROA terhadap guncangan dari IPI, IHK, BI rate. 3) Respon BOPO terhadap guncangan dari IPI, IHK, BI rate. 4) Respon LDR terhadap guncangan dari IPI, IHK, BI rate. 5) seberapa besar kontribusi variabel makro (IPI, IHK, dan BI rate) dalam pengukuran kinerja perbankan indikator (ROA, BOPO, LDR) di Indonesia. Untuk menjawab semua pertanyaan pada penelitian ini menggunakan metode analisis VAR jika tidak terkointegrasi, jika terkointegrasi maka akan digunakan analisis VECM.

Persamaan Jangka Panjang

$\begin{array}{ll}\operatorname{LogROA} & =\alpha_{0}+\beta_{1} \text { IPI I }_{t-\mathrm{j}}+\beta_{2} \mathrm{IHK}_{\mathrm{t}-\mathrm{j}}+\beta_{3} \text { BIrate }_{t-\mathrm{j}}+\varepsilon_{\mathrm{t}} \\ \operatorname{LogBOPO}_{\mathrm{B}} & =\alpha_{0}+\beta_{1} \text { IPI }_{\mathrm{t}-\mathrm{j}}+\beta_{2} \mathrm{IHK}_{\mathrm{t}-\mathrm{j}}+\beta_{3} \text { BIrate }_{t-\mathrm{j}}+\varepsilon_{\mathrm{t}} \\ \operatorname{LogLDR} & =\alpha_{0}+\beta_{1} \text { IPI }_{\mathrm{t}-\mathrm{j}}+\beta_{2} \mathrm{IHK}_{\mathrm{t}-\mathrm{j}}+\beta_{3} \text { BIrate }_{t-\mathrm{j}}+\varepsilon_{\mathrm{t}}\end{array}$

Persamaan Jangka Pendek

$\Delta \log \mathrm{ROA}_{\mathrm{t}}=\alpha_{0}+\chi_{1} \Delta \mathrm{IPI}_{\mathrm{t}}+\chi_{2} \Delta \mathrm{IHK}_{\mathrm{t}}+\chi_{3} \Delta \mathrm{BI} \mathrm{RATE}_{\mathrm{t}}+\chi_{4} \mathrm{Ect}+\varepsilon_{\mathrm{t}}$

$\Delta \operatorname{LogBOPO} \mathrm{B}_{\mathrm{t}}=\alpha_{0}+\chi_{1} \Delta \mathrm{IPI}_{\mathrm{t}}+\chi_{2} \Delta \mathrm{IHK}_{\mathrm{t}}+\chi_{3} \Delta \mathrm{BI} \mathrm{RATE}_{\mathrm{t}}+\chi_{4} \mathrm{Ect}+\varepsilon_{\mathrm{t}}$. (5)

$\Delta \log \mathrm{LDR}_{\mathrm{t}}=\alpha_{0}+\chi_{1} \Delta \mathrm{IPI}_{\mathrm{t}}+\chi_{2} \Delta \mathrm{IHK}_{\mathrm{t}}+\chi_{3} \Delta \mathrm{BI} \mathrm{RATE}_{\mathrm{t}}+\chi_{4} \mathrm{Ect}+\varepsilon_{\mathrm{t}} .$. (6)

Dimana:

IPI = Industrial production index

IHK = Indeks harga konsumen

BIrate $=$ Suku bunga $\mathrm{BI}$ rate

$\chi_{1}, \chi_{2}, \chi_{3}, \chi_{4}, \chi_{5}, \chi_{6}=$ Koefisien hubungan jangka pendek

$\alpha_{0} \quad=$ Intercept Konstanta

$\beta_{1}, \beta_{2}, \beta_{3}, \beta_{4}, \beta_{5}, \beta_{6} \quad=$ Koefisien hubungan jangka panjang

$\mathrm{ECT}=$ Erroe term

$\varepsilon=$ Error term

$\mathrm{j} \quad=$ Parameter $(\operatorname{lag} 1,2, \ldots . \mathrm{dst})$

\section{HASIL DAN PEMBAHASAN}

\section{Uji stasioneritas}

Dalam memenuhi salah satu asumsi dalam uji data time series dengan menggunakan analisis model VAR atau VECM, maka perlu dilakukan terlebih dahulu uji Stasioneritas. Uji stasioneritas yang digunakan pada penelitian ini adalah dengan menggunakan uji akar-akar unit (unit root test) dengan menggunakan metode Augmented Dickey Fuller Test (ADF test)

Tabel 1. Hasil uji unit root test pada first difference

\begin{tabular}{llccccl}
\hline \multirow{2}{*}{ Variabel } & ADF T- & \multicolumn{3}{c}{ Critical Value } & \multirow{2}{*}{ Hasil } & \multirow{2}{*}{ Kesimpulan } \\
\cline { 3 - 5 } & Statistic & $\mathbf{1 \%}$ & $\mathbf{5 \%}$ & $\mathbf{1 0 \%}$ & & \\
\hline ROA & -7.9395 & -3.500 & -2.892 & -2.583 & Tolak $H_{0}$ & Stasioner \\
BOPO & -3.796 & -3.508 & -2.895 & -2.584 & Tolak $H_{0}$ & Stasioner \\
LDR & -10.267 & -3.499 & -2.891 & -2.582 & Tolak $H_{0}$ & Stasioner \\
IPI & -5.461 & -3.507 & -2.895 & -2.584 & Tolak $H_{0}$ & Stasioner \\
IHK & -9.738 & -3.499 & -2.891 & -2.582 & Tolak $H_{0}$ & Stasioner \\
BI rate & -4.529 & -3.499 & -2.891 & -2.583 & Tolak $H_{0}$ & Stasioner \\
\hline
\end{tabular}

Sumber : Data diolah, 2019 
Pada tabel 1 menunjukan hasil estimasi unit root pada tingkat first difference untuk semua variabel sudah stasioner. Hal ini berarti bahwa data yang digunakan pada penelitian ini terintegrasi pada ordo satu atau dapat disingkat menjadi I(1) sehingga data terbebas dari masalah regresi lancung (spurious reggression). Oleh karena itu syarat stasioner sudah terpenuhi maka tahap selanjutnya dapat dilakukan pengolahan data lebih lanjut.

\section{Penentuan lag optimum}

Penentuan lag optimum pada penelitian ini menggunakan metode yang umum digunakan yaitu dengan menggunakan nilai Akaike Information Criterion (AIC) yang terkecil. Berdasarkan nilai Akaike Information Criterion (AIC) diperoleh panjang lag optimum adalah 2. Sehingga nilai lag yang akan digunakan untuk penelitian selanjutnya adalah lag 2. Hasil penentuan panjang lag ditampilkan pada tabel-tabel berikut ini :

Tabel 2. Hasil penentuan lag optimum model 1 (ROA-variabel makroekonomi)

\begin{tabular}{lc}
\hline Lag & Akaike Information Criterion (AIC) \\
\hline 0 & 15.21871 \\
1 & 6.908378 \\
2 & $6.886530^{*}$ \\
3 & 6.992721 \\
4 & 7.191108 \\
5 & 7.324155 \\
\hline
\end{tabular}

Sumber : Data diolah, 2019

Tabel 3. Hasil penentuan lag optimum model 3 (BOPO -variabel makroekonomi)

\begin{tabular}{|c|c|}
\hline Lag & Akaike Information Criterion (AIC) \\
\hline 1 & 7.318899 \\
\hline 2 & $7.216451^{*}$ \\
\hline 3 & 7.251031 \\
\hline 4 & 7.366318 \\
\hline
\end{tabular}

Sumber : Data diolah, 2019

Tabel 4. Hasil penentuan lag optimum model 4 (LDR -variabel makroekonomi)

\begin{tabular}{|c|c|}
\hline Lag & Akaike Information Criterion (AIC) \\
\hline 1 & 3.985619 \\
\hline 2 & $3.943112 *$ \\
\hline 3 & 4.037258 \\
\hline
\end{tabular}

Sumber : Data diolah, 2019

Keterangan

(*) : Nilai Akaike information criterion (AIC) terkecil

Berdasarkan Tabel 2-4 penentuan lag optimum yang digunakan dalam penelitian ini adalah lag 2 untuk ketiga model persamaan VAR/VECM dalam penelitian ini, selanjutnya lag yang digunakan pada pengujian selanjutnya adalah lag 2 . 


\section{Uji stabilitas VAR}

Untuk menguji stabil atau tidaknya estimasi VAR yang telah dibentuk maka dilakukan pengecekan kondisi stabilitas (stability condition check) dengan menggunakan roots of characteristic polinomial dan inverse roots of AR characteristic polynomial.

Tabel 5. Hasil pengujian roots of AR characteristic polynomial

\begin{tabular}{ll}
\hline Model Persamaan & Kisaran Modulus \\
\hline Model Persamaan 1 & $0.080433-0.972828$ \\
Model Persamaan 2 & $0.063842-0.990695$ \\
Model Persamaan 3 & $0.044001-0.994039$ \\
\hline
\end{tabular}

Sumber : Data diolah, 2019

Berdasarkan Tabel 5 menunjukan bahwa nilai modulus semua model persamaan kurang dari 1 sehingga dapat disimpulkan bahwa model VAR tersebut sudah valid. Selanjuntya dilakukan pengujian stabilitas VAR dengan menggunakan inverse roots $A R$ characteristic polynomial ditampilkan dalam gambar berikut :

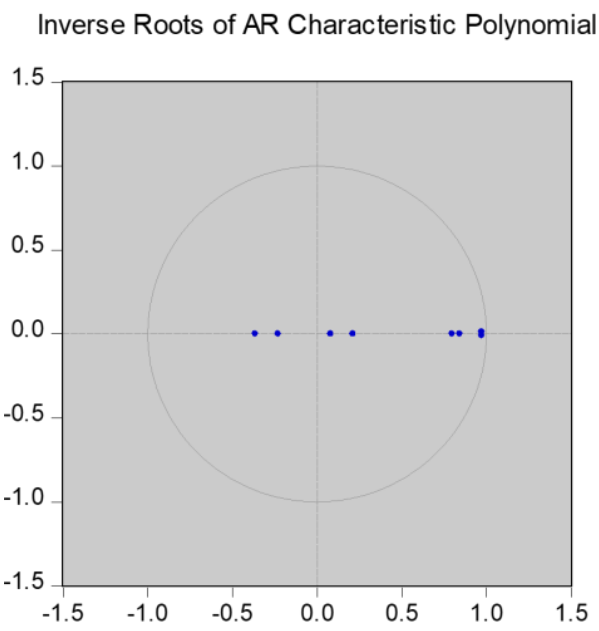

Gambar 1. Uji stabilitas VAR Model Persamaan 1 Dengan Menggunakan Inverse Roots of AR Characteristic Polynomial

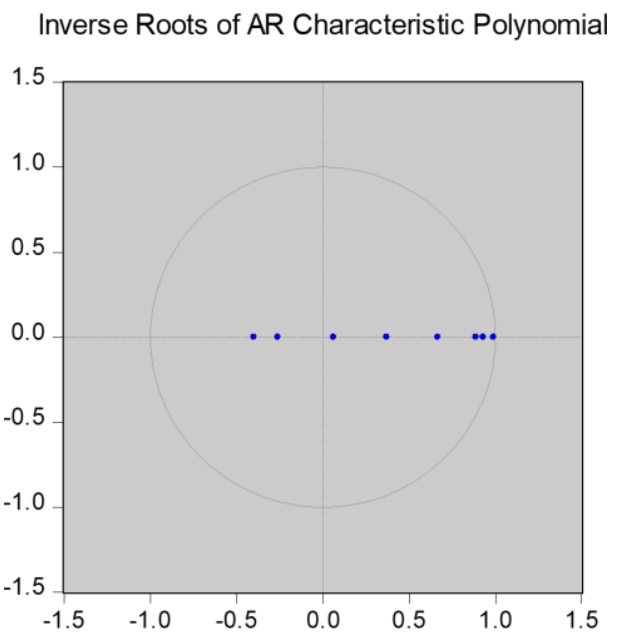

Gambar 2. Uji stabilitas VAR model persamaan 2 dengan menggunakan inverse roots of AR characteristic polynomial 


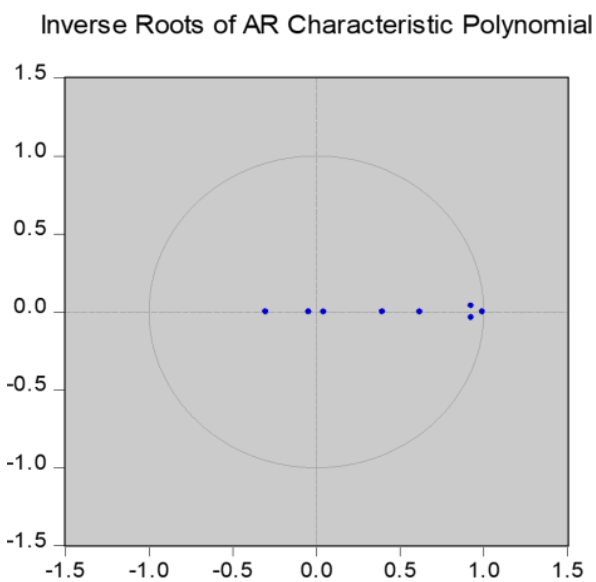

Gambar 3. Uji stabilitas VAR model persamaan 3 dengan menggunakan inverse roots of AR characteristic polynomial

Berdasarkan Gambar 1 sampai dengan gambar 3 yaitu pengujian stabilitas VAR dengan menggunakan inverse roots of AR characteristic polynomial untuk semua model persamaan menujukan bahwa titik-titik pada lingkaran atau penyebaran data tidak keluar dari lingkaran hal ini berarti bahwa data valid untuk dilakukan analisis lebih lanjut dengan menggunkan VAR. Oleh karena itu pengujian stabilitas VAR dengan menggunakan dan roots of characteristic polynomial dan inverse roots $A R$ characteristic polynomial sudah valid yang berarti bahwa hasil analisis impulse response function dan variance decomposition dalam estimasi VAR valid.

\section{Uji kointegrasi}

Engle Granger mengungkapkan sebuah konsep kointegrasi pada tahun 1987 sebuah fenomena kombinasi linier dari dua atau lebih variabel yang tidak stationer akan menjadi stationer. Kombinasi linier ini dikenal dengan istilah persamaan kointegrasi dan dapat diinterpretasikan sebagai hubungan keseimbangan jangka panjang di antara variabel. pengujian kointegrasi ini dilakukan sebelum melakukan pengujian lebih lanjut dan menentukan apakah VAR atau VECM yang lebih tepat digunakan dalam penelitian ini.

Pada penelitian ini, uji kointegrasi untuk mengetahui jumlah persamaan kointegerasi dilakukan melaui Johansen Cointegration test dengan lag optimum adalah 2 sesuai dengan penentuan lag optimum berdasarkan AIC yang telah dilakukan sebelumnya. Metode Johansen Cointegration Test ini dilakukan dengan membandingkan antara trace statistics dengan critical value dengan menggunakan tingkat signifikansi sebesar 5 persen. Jika trace statistic lebih besar dari critical value maka terdapat kointegrasi dalam sistem persamaan tersebut. Hasil uji kointegrasi pada penelitian ini dapa dilihat pada tabel 7 sebagai berikut :

Tabel 6. Hasil uji kointegrasi model persamaan 1 (ROA - variabel makro)

\begin{tabular}{lllll}
\hline Hypothesized & Eigenvalue & $\begin{array}{c}\text { Trace } \\
\text { Statistic }\end{array}$ & $\begin{array}{c}\mathbf{0 . 0 5} \\
\text { Critical Value }\end{array}$ & Prob.** \\
\hline \hline None $*$ & 0.323488 & 66.66697 & 55.24578 & 0.0036 \\
At most 1 & 0.142303 & 30.32209 & 35.01090 & 0.1456 \\
At most 2 & 0.103991 & 16.04615 & 18.39771 & 0.1035 \\
At most 3 $*$ & 0.060807 & 5.834295 & 3.841466 & 0.0157 \\
\hline \hline
\end{tabular}

Sumber : Data diolah, 2019 
Tabel 7. Hasil uji kointegrasi model persamaan 2 (BOPO - variabel makro)

\begin{tabular}{lllll}
\hline \hline \multirow{2}{*}{ Hypothesized Eigenvalue } & \multicolumn{1}{c}{ Trace } & \multicolumn{1}{c}{$\mathbf{0 . 0 5}$} & \multirow{2}{*}{ Prob.** } \\
\cline { 3 - 4 } & & Statistic & Critical Value & \\
\hline \hline None $*$ & 0.268874 & 58.79100 & 55.24578 & 0.0236 \\
At most 1 & 0.134658 & 28.72679 & 35.01090 & 0.2006 \\
At most 2 & 0.120060 & 14.84224 & 18.39771 & 0.1467 \\
At most 3 & 0.026352 & 2.563688 & 3.841466 & 0.1093 \\
\hline \hline
\end{tabular}

Sumber : Data diolah, 2019

Tabel 8. Hasil uji kointegrasi model persamaan 3 (LDR - variabel makro)

\begin{tabular}{llccc}
\hline \hline \multirow{2}{*}{ Hypothesized Eigenvalue } & Trace & \multicolumn{1}{c}{$\mathbf{0 . 0 5}$} & \\
\cline { 3 - 4 } & & Statistic & Critical Value & Prob.** \\
\hline \hline None $*$ & 0.275312 & 57.87434 & 55.24578 & 0.0288 \\
At most 1 & 0.146575 & 26.96100 & 35.01090 & 0.2779 \\
At most 2 & 0.085477 & 11.74517 & 18.39771 & 0.3283 \\
At most 3 & 0.032455 & 3.167371 & 3.841466 & 0.0751 \\
\hline \hline
\end{tabular}

Sumber : Data diolah, 2019

Keterangan $(*)$ : Nilai trace statistik lebih besar dari critical value $(0,05)$

Berdasarkan Tabel 6-8 menunjukan bahwa nilai trace statistic $\mathrm{r}=0$ lebih besar dari critical value dengan tingkat signifikansi sebesar 5 persen, yaitu 66,66697 lebih besar dari 55,24578 untuk model persamaan 1 hubungan ROA dengan (IPI, IHK, dan BI rate). 58,79100 lebih besar dari 55,24578 untuk model persamaan 2 hubungan BOPO dengan (IPI, IHK, dan BI rate). 57,87434 lebih besar dari 55,24578 untuk model persamaan 3 hubungan LDR dengan (IPI, IHK, dan BI rate). Hal ini berarti bahwa hipotetis nol yang menyatakan bahwa tidak ada kointegrasi pada variabel-variabel yang digunakan ini ditolak dan hipotesis alternatif yang menyatakan bahwa ada kointegrasi diterima. Dengan demikian, dari hasil uji koitegrasi mengindikasi bahwa di antara pergerakan industrial production index (IPI), indeks harga konsumen (IHK) dan suku bunga $\mathrm{BI}$ rate memiliki hubungan stabilitas/keseimbangan dan kesamaan pergerakan dalam jangka panjang. Oleh karena itu, dalam setiap periode jangka pendek, seluruh variabel cenderung saling menyesuaikan untuk mencapai keseimbangan ekuilibrium jangka panjangnya. Dengan demikian model yang tepat untuk digunakan dalam penelitian ini adalah Vector Error Correction Model (VECM) bukan Variance Auto regression (VAR) karena variabel yang digunakan terkointegrasi dan stationer pada tingkat first difference. Hal ini merupakan syarat yang harus dipenuhi dalam pengujian model VECM dan model ini sesuai dengan penelitian yang dilakukan oleh Mujica dan Saens (2015).

\section{Estimasi VECM}

Setelah dilakukan pengujian, dimana data stationer pada ordo first difference, stabil dan terkointegrasi di jangka panjang dan jangka pendek diperkirakan menggunakan vektor koreksi kesalahan model (VECM). 


\section{Estimasi jangka panjang model persamaan 1 (ROA - variabel makro)}

Hasil estimasi pada variabel penelitian yang diperolah dapat dikatakan berpengaruh signifikan apabila nilai t-hitung lebih besar dari nilai t-tabel dengan tingkat signifikansi sebesar $1 \%(2,3658), 5 \%(1,6608)$, dan $10 \%(1,290)$.

Tabel 9. Hasil estimasi VECM jangka panjang

\begin{tabular}{llll}
\hline Variabel & Koefisien & t-statistik & Keterangan \\
\hline ROA (-1) & 1.000000 & & \\
IPI (-1) & 0.00759 & {$[3.16470]^{*}$} & Signifikan \\
IHK (-1) & -0.01376 & {$[-5.68989]^{*}$} & Signifikan \\
BI RATE (-1) & -0.02207 & {$[-0.79757]$} & Tidak Signifikan \\
\hline
\end{tabular}

Sumber : Data diolah, 2019

Keterangan:

[ ] : Menunjukkan t-hitung

* : Berdasarkan tingkat keyakinan $99 \%(\alpha=1 \%)$

** : Berdasarkan tingkat keyakinan $95 \%(\alpha=5 \%)$

$* * *$ : Berdasarkan tingkat keyakinan $90 \%(\alpha=10 \%)$

Ketika jangka panjang variabel ROA memiliki hubungan positif dan signifikan dengan variabel IPI. IPI merupakan indikator makroekonomi untuk mengukur output produksi riil sektor industri. Indeks Produksi Industri biasanya disusun untuk mengukur kenaikan dan penurunan produksi yang merupakan proksi dari Gross Domestic Product (GDP) yang menggambarkan pendapatan nasional (Nina, 2017). Jika pendapatan nasional mengalami peningkatkan maka akan meningkatkan keuntungan perusahaan, dikarenakan meningkatnya pendapatan perusahaan akan mempengaruhi pendapatan masyarakat, dengan pendapatan masyarakat yang tinggi akan membuat pola saving masyarakat di perbankan akan meningkat. Teori ini menunjukkan bahwa IPI memiliki hubungan positif terhadap ROA.

Hasil estimasi di atas dalam jangka panjang ROA memiliki hubungan negatif dan signifikan dengan IHK yang artinya yaitu ketika terjadi inflasi akan mengakibatkan konsumsi yang dikeluarkan oleh masyarakat yang memerlukan dana sangat besar. Dengan kenaikan konsumsi masyarakat akan mempengaruhi saving yang dilakukan oleh masyarakat, dimana masyarakat lebih banyak mengeluarkan untuk konsumsi dibandingkan menyimpan uang di bank. Akibatnya, Dana Pihak Ketiga (DPK) bank akan mengalami penurunan yang akan menurunkan profit bank. Teori ini menunjukkan bahwa IHK sebagai proksi dari inflasi mempunyai hubungan negatif dengan ROA.

Estimasi jangka panjang ROA memiliki hubungan negatif dan tidak signifikan dengan $\mathrm{BI}$ rate yang artinya ketika BI rate mengalami peningkatan yang berakibat suku bunga juga ikut meningkat, sehingga akan meningkatkan pola saving pada masyarakat, yang akan menurunkan profitabilitas bank, namun disisi lain profitabilitas bank juga dipengaruhi oleh faktor internal yang berupa, margin laba bersih, perputaran total aktiva, laba bersih, total biaya, dan lain-lain. Sehingga dalam kasus ini ROA lebih dominan dipengaruhi oleh faktor internal dibandingkan faktor eksternal. Sehingga, ROA tidak memiliki hubungan signifikan dengan BI rate (Kasmir, 2013).

\section{Estimasi jangka pendek model persamaan 1 (ROA - variabel makro)}

Berikut ini merupakan Tabel 10 ringkasan hasil estimasi VECM untuk jangka pendek : 
Tabel 10. Hasil estimasi VECM jangka pendek

\begin{tabular}{llll}
\hline Variabel & Koefisien & T-statistik & Keterangan \\
\hline ECT & -0.079705 & {$[-1.99179]^{* * *}$} & Signifikan \\
D(ROA(-1)) & -0.302287 & {$[-2.86981]^{*}$} & Signifikan \\
D(ROA(-2)) & -0.114836 & {$[-1.10756]$} & Tidak Signifikan \\
D(IPI(-1)) & 0.0000646 & {$[0.05282]$} & Tidak Signifikan \\
D(IPI(-2)) & -0.001188 & {$[-1.00208]$} & Tidak Signifikan \\
D(IHK(-1)) & 0.00091 & {$[0.78884]$} & Tidak Signifikan \\
D(IHK(-2)) & -0.002168 & {$[-1.87637]^{* *}$} & Signifikan \\
D(BIRATE(-1)) & 0.020868 & {$[0.85098]$} & Tidak Signifikan \\
D(BIRATE(-2)) & -0.036016 & {$[-1.45415]^{*}$} & Signifikan \\
\hline Sumber:Datadiolah
\end{tabular}

Sumber : Data diolah, 2019

Keterangan:

[ ] : Menunjukkan t-hitung

* : Berdasarkan tingkat keyakinan $99 \%(\alpha=1 \%)$

** : Berdasarkan tingkat keyakinan $95 \%(\alpha=5 \%)$

$* * *$ : Berdasarkan tingkat keyakinan $90 \%(\alpha=10 \%)$

Hasil estimasi VECM hubungan jangka pendek ROA dengan IPI. Ketika jangka pendek ROA memiliki hubungan negatif namun tidak signifikan terhadap IPI pada lag2. Indeks Produksi Industri merupakan indikator makroekonomi yang dirilis oleh dewan US Federal Reserve Bank, mengukur perubahan nilai total inflasi yang disesuaikan dengan output produksi dari produsen, perusahaan pertambangan, dan insutri gas. IPI merupakan proksi dari Gross Domestic Product (GDP) yang menggambarkan pendapatan nasional dilihat dari sektor produksi industrinya (Nina, 2017). Ketika meningkatnya pendapatan nasional akan mempengaruhi pendapatan perusahaan, dan berakibat meningkatnya pendapatan masyarakat. Namun dalam jangka pendek, kenaikan pendapatan nasional tidak sepenuhnya langsung di respon oleh masyarakat dengan mengubah pola saving atau keinginan untuk menyimpan uangnya sehingga dalam kasus jangka pendek tersebut ROA pada perbankan tidak mengalami peningkatan seiring dengan peningkatan IPI di suatu negara atau ROA tidak memiliki hubungan dengan IPI dalam jangka pendek.

Hasil estimasi jangka pendek, ROA memiliki hubungan negatif dan signifikan dengan IHK. Ketika terjadi inflasi akan mengakibatkan konsumsi yang dikeluarkan oleh masyarakat meningkat, pola konsumsi masyarakat akan meningkat dan menurunkan pola saving sehingga, kenaikan IHK yang menjadi proksi dari inflasi dalam jangka pendek akan membuat profitabilitas bank menurun sehingga ROA perbankan juga menurun seiring kenaikan IHK.

Hasil estimasi jangka pendek ROA memiliki hubungan negatif dan signifikan tdengan BI rate. Ketika peningkatan suku bunga BI rate akan meningkatkan suku bunga perbankan, ketika suku bunga bank keinginan masyarakat untuk menabung juga meningkat, sehingga profitabilitas bank meningkat, namun sisi lain dalam perbankan beban bunga yang harus dibayarkan oleh bank ke nasabah juga meningkat sehingga secara tidak langsung dalam jangka pendek BI rate menurunkan ROA.

Estimasi jangka panjang model persamaan 2 (BOPO - variabel makro) 
Hasil estimasi di atas hubungan jangka panjang BOPO dengan IPI. Dalam jangka panjang variabel IPI memiliki hubungan negatif dan signifikan dengan BOPO. IPI yang merupakan proksi dari Gross Domestic Product (GDP) yang menggambarkan pendapatan nasional dilihat dari sektor produksi industrinya (Shu, 2002). Jika pendapatan nasional mengalami peningkatan maka akan meningkatkan keuntungan pada suatu perusahaan, dikarenakan meningkatnya pendapatan perusahaan akan mempengaruhi pendapatan masyarakat, dengan pendapatan masyarakat yang tinggi akan membuat pola saving masyarakat di perbankan akan meningkat sehingga indikator beban operasional juga meningkat yang menyebabkan biaya operasional bank yang menjadi tolak ukur pengukuran bopo juga meningkat. Namun dari sisi perbankan ketika BOPO mengalami peningkatan melebihi 93,5 persen maka dapat disimpulkan kinerja bank tersebut tidak baik dikarenakan nilai BOPO melebihi syarat maksimal yaitu sebesar 93,5\% hasil ini diperoleh dari ketentuan dari OJK sebagai tolak ukur pegukuran kinerja bank.

Tabel 11. Hasil estimasi VECM jangka panjang

\begin{tabular}{|c|c|c|c|}
\hline Variabel & Koefisien & T-statistik & Keterangan \\
\hline $\mathrm{BOPO}(-1)$ & 1.000000 & & \\
\hline $\operatorname{IPI}(-1)$ & -0.798412 & {$[-5.56260]^{*}$} & Signifikan \\
\hline $\operatorname{IHK}(-1)$ & -0.053888 & {$[-1.18249]$} & Tidak Signifikan \\
\hline BIRATE(-1) & -0.437705 & {$[-1.17848]$} & Tidak Signifikan \\
\hline $\mathrm{C}$ & 82.1974 & & \\
\hline \multicolumn{4}{|c|}{ Sumber : Data diolah, 2019} \\
\hline \multicolumn{4}{|c|}{ [ ] : Menunjukkan t-hitung } \\
\hline \multicolumn{4}{|c|}{ * $\quad$ : Berdasarkan tingkat keyakinan $99 \%(\alpha=1 \%)$} \\
\hline \multicolumn{4}{|c|}{$* * \quad$ : Berdasarkan tingkat keyakinan $95 \%(\alpha=5 \%)$} \\
\hline \multicolumn{4}{|c|}{ *** : Berdasarkan tingkat keyakinan $90 \%(\alpha=10 \%)$} \\
\hline
\end{tabular}

BOPO memiliki hubungan negatif dan tidak signifikan dengan IHK, yang berarti ketika terjadi peningkatan IHK maka pola konsumsi masyarakat meningkat, dan mengurangi saving sehingga beban atau biaya bunga dana pihak ketiga menurun akibat berkurangnya dana pihak ketiga perbankan. Namun dalam pengukuran kinerja perbankan (BOPO) tersebut tidak sepenuhnya disebabkan akibat adanya IHK yang meningkat namun juga disebabkan dari faktor internal diantaranya yaitu laba bersih, penjualan, total biaya, dan lain-lain. Sehingga dalam kasus ini BOPO lebih dominan dipengaruhi oleh faktor internal dibandingkan faktor eksternal. (Kasmir, 2013).

Hasil estimasi jangka panjang BOPO terhadap BI rate, BOPO memiliki hubungan negatif dan tidak signifikan dengan BI rate. Ketika Bank Indonesia menaikan suku bunga kebijakan BI rate maka suku bunga perbankan juga meningkat, dimana masyarakat lebih memilih menyimpan dana nya di perbankan (saving) sehingga rasio profitabilitas meningkat akibat adanya peningkatan pola saving masyarakat, namun di sisi perbankan ketika peningkatan BOPO masih dalam tahap normal (tidak lebih dari 93,5) maka dapat dikatakan BOPO tidak memiliki hubungan signifikan terhadap kenaikan Bi rate (Siregar, 2015).

\section{Estimasi jangka pendek model persamaan 2 (BOPO - variabel makro)}

Berikut ini merupakan tabel ringkasan hasil estimasi VECM untuk jangka pendek :

Tabel 12. Hasil estimasi VECM jangka pendek 


\begin{tabular}{llll}
\hline Variabel & Koefisien & T-statistik & Keterangan \\
\hline ECT & -0.006046 & {$[-1.98439]^{* *}$} & Signifikan \\
D(BOPO(-1)) & -0.490151 & {$[-4.68711]^{*}$} & Signifikan \\
D(BOPO(-2)) & -0.27377 & {$[-2.58752]^{*}$} & Signifikan \\
D(IPI(-1)) & -0.00431 & {$[-2.06501]^{* *}$} & Signifikan \\
D(IPI(-2)) & -0.002777 & {$[-1.68442]^{* *}$} & Signifikan \\
D(IHK(-1)) & -0.000184 & {$[-0.13524]$} & Tidak Signifikan \\
D(IHK(-2)) & 0.000208 & {$[0.15367]$} & Tidak Signifikan \\
D(BIRATE(-1)) & 0.011874 & {$[0.40475]$} & Tidak Signifikan \\
D(BIRATE(-2)) & -0.0000909 & {$[-0.00303]$} & Tidak Signifikan \\
C & -0.0065910 & {$[-0.62280]$} & Tidak Signifikan \\
\hline Sumber: Data
\end{tabular}

Sumber : Data diolah, 2019

[ ] : Menunjukkan t-hitung

* : Berdasarkan tingkat keyakinan $99 \%(\alpha=1 \%)$

** : Berdasarkan tingkat keyakinan $95 \%(\alpha=5 \%)$

*** : Berdasarkan tingkat keyakinan $90 \%(\alpha=10 \%)$

Hasil estimasi VECM hubungan jangka pendek BOPO dengan IPI. Ketika jangka pendek BOPO memiliki hubungan negatif dan signifikan dengan IPI. IPI yang merupakan proksi dari Gross Domestic Product (GDP) yang menggambarkan pendapatan nasional dilihat dari sektor produksi industrinya (Nina, 2017). Jika pendapatan nasional mengalami peningkatan maka akan meningkatkan keuntungan pada suatu perusahaan, dikarenakan meningkatnya pendapatan nasional akan mempengaruhi pendapatan masyarakat, dengan pendapatan masyarakat yang tinggi akan membuat pola saving masyarakat di perbankan akan meningkat sehingga indikator beban operasional juga meningkat yang menyebabkan biaya operasional bank yang menjadi tolak ukur pengukuran bopo juga meningkat. Namun dari sisi perbankan ketika BOPO mengalami peningkatan melebihi 93,5 persen maka dapat disimpulkan kinerja bank tersebut tidak baik dikarenakan nilai BOPO melebihi syarat maksimal yaitu sebesar 93,5\% hasil ini diperoleh dari ketentuan dari OJK sebagai tolak ukur pegukuran kinerja bank (Akani, 2016).

Estimasi VECM pada jangka pendek BI rate memiliki hubungan negatif dan tidak signifikan dengan BOPO pada lag ke-2, hal ini ketika Bank Indonesia menaikan suku bunga kebijakan BI rate maka suku bunga perbankan juga meningkat, dimana masyarakat lebih memilih menyimpan dana nya di perbankan (saving) sehingga rasio profitabilitas meningkat akibat adanya peningkatan pola saving masyarakat, namun di sisi perbankan ketika peningkatan BOPO masih dalam tahap normal (tidak lebih dari 93,5) maka dapat dikatakan BOPO tidak memiliki hubungan signifikan terhadap kenaikan BI rate (Siregar, 2015).

Hasil estimasi VECM jangka pendek BOPO memiliki hubungan positif dan tidak signifikan dengan IHK pada lag ke-2, ketika terjadi inflasi tetapi tidak diantisipasi penuh oleh pihak bank maka suku bunga mengalami penyesuaian yang lamban, sehingga peningkatan biaya lebih cepat dibandingkan peningkatan pendapatan. Namun, ketika peningkatan IHK dalam jangka pendek tidak langsung di respon dan tidak cepat dalam penyesuaian di perbankan maka kenaikan IHK tidak memiliki hubungan signifikan dengan BOPO dalam jangka pendek. 
Searah dari hasil estimasi di atas sehingga dapat disimpulkan bahwa, baik dalam jangka panjang maupun jangka pendek variabel Indeks Harga Konsumen (IHK) dan BI rate tidak memiliki hubungan signifikan terhadap BOPO.

\section{Estimasi jangka panjang model persamaan 3 (LDR - variabel makro)}

Hasil estimasi di atas hubungan jangka panjang LDR dengan IPI, IHK dan BI rate. Ketika jangka panjang LDR memiliki hubungan negatif dan signifikan dengan IPI. IPI yang merupakan proksi dari Gross Domestic Product (GDP) yang menggambarkan pendapatan nasional dilihat dari sektor produksi industri nya (Nina, 2017). Jika pendapatan nasional mengalami peningkatan maka akan mempengaruhi pendapatan perusahaan yang berakibat meningkatnya pendapatan masyarakat, dengan pendapatan masyarakat yang meningkat akan membuat pola saving masyarakat, ketika saving meningkat maka secara langsung sisi pinjaman berkurang yang mengakibatkan rasio pinjaman deposito juga menurun. Hal ini menunjukkan bahwa IPI memiliki hubungan negatif dengan LDR.

Tabel 13. Hasil estimasi VECM jangka panjang

\begin{tabular}{llll}
\hline Variabel & Koefisien & T-statistik & Keterangan \\
\hline LDR(-1) & 1.000000 & & \\
IPI(-1) & -0.004783 & {$[-8.41366]^{*}$} & Signifikan \\
IHK(-1) & -0.003825 & {$[-3.83196]^{*}$} & Signifikan \\
BIRATE(-1) & -0.03417 & {$[-4.19403]^{*}$} & Signifikan \\
C & -3.195057 & {$[-16.8338]^{*}$} & Signifikan \\
\hline
\end{tabular}

Sumber : Data diolah, 2019

[ ] : Menunjukan t-hitung

* : Berdasarkan tingkat keyakinan $99 \%(\alpha=1 \%)$

** : Berdasarkan tingkat keyakinan 95\% $(\alpha=5 \%)$

*** : Berdasarkan tingkat keyakinan $90 \%(\alpha=10 \%)$

$\mathrm{BI}$ rate memiliki hubungan negatif dan signifikan dengan LDR dalam jangka panjang. Ketika BI rate meningkat maka suku bunga bank juga ikut meningkat yang berarti pola masyarakat cenderung menyimpan uang dibandingkan meminjam uang sehingga rasio pinjaman deposito menurun. Hal ini menunjukkan bahwa BI rate memiliki hubungan negatif dengan LDR.

LDR memiliki hubungan negatif dan signifikan dengan IHK. Hal ini dikarenakan dengan ketika terjadi inflasi maka masyarakat akan cenderung lebih banyak meminjam untuk kebutuhan konsumsi, namun dalam kasus lain ketika terjadi kenaikan inflasi, bank membatasi jumlah pinjaman terhadap nasabah dikarenakan kekhawatiran terjadi nya kredit macet akibat tidak mampunya masyarakat (debitur) untuk mengembalikan atau membayar pinjaman. Sehingga dalam kasus ini diterapkannya pembuatan kebijakan membatasi pinjaman membuat LDR dan IHK memiliki hubungan negatif.

\section{Estimasi jangka pendek model persamaan 3 (LDR - variabel makro)}

Hasil estimasi jangka pendek VECM, LDR memiliki hubungan positif dan tidak signifikan dengan IPI pada lag ke-2, hal ini dikarenakan dengan menurunnya IPI yang terjadi maka suatu bank akan membuat kebijakan dalam menyalurkan kredit dengan prinsip kehati-hatian dengan alasan pihak bank meragukan kemampuan debitur 
(masyarakat) dalam mengembalikan pinjaman dari bank dimana yang menjadi tolak ukur adalah capacity nya sehingga, jumlah kredit pada bank cenderung akan stagnan atau tetap. Dalam kasus ini pembuatan kebijakan ini bertujuan untuk mengurangi jumlah pinjaman pada bank dalam jangka pendek dan tidak untuk diterapkan dalam jangka panjang karena, sifat dari kebijakan ini sementara untuk meminimalisir efek dari menurunnya IPI, sehingga dalam kasus seperti ini LDR diasumsikan tidak memiliki hubungan dengan IPI. Berikut ini merupakan Tabel 14 ringkasan hasil estimasi VECM untuk jangka pendek :

Tabel 14. Hasil estimasi VECM jangka pendek

\begin{tabular}{llll}
\hline Variabel & Koefisien & T-statistik & Keterangan \\
\hline ECT & -0.13068 & {$[-4.08108]^{*}$} & Signifikan \\
D(LDR(-1)) & 0.038982 & {$[0.38555]$} & Tidak Signifikan \\
D(LDR(-2)) & -0.065073 & {$[-0.65349]$} & Tidak Signifikan \\
D(IPI(-1)) & 0.00024 & {$[0.76575]$} & Tidak Signifikan \\
D(IPI(-2)) & 0.0000234 & {$[0.07832]$} & Tidak Signifikan \\
D(IHK(-1)) & -0.000256 & {$[-0.93463]$} & Tidak Signifikan \\
D(IHK(-2)) & -0.000516 & {$[-1.88974]^{* *}$} & Signifikan \\
D(BIRATE(-1)) & 0.001632 & {$[0.27993]$} & Tidak Signifikan \\
D(BIRATE(-2)) & -0.0000674 & {$[-0.01154]$} & Tidak Signifikan \\
\hline Sumber : Data diolah
\end{tabular}

Sumber : Data diolah, 2019

Keterangan:

[ ] : Menunjukan t-hitung

* : Berdasarkan tingkat keyakinan $99 \%(\alpha=1 \%)$

** : Berdasarkan tingkat keyakinan $95 \%(\alpha=5 \%)$

*** : Berdasarkan tingkat keyakinan $90 \%(\alpha=10 \%)$

BI rate memiliki hubungan negatif dan tidak signifikan dengan LDR pada lag ke- 2. Ketika BI rate meningkat maka suku bunga bank juga ikut meningkat yang berarti pola masyarakat cenderung menyimpan uang dibandingkan meminjam uang sehingga rasio pinjaman deposito menurun. Namun pengukuran kinerja perbankan (LDR) tidak sepenuhnya dipengaruhi oleh faktor eksternal (BI rate) namun, pengukuran kinerja perbankan (LDR) juga dipengaruhi oleh faktor internal yaitu, jangka waktu kredit, administrasi, dan pembelian aktiva tetap. Sehingga dalam kasus jangka pendek ini faktor yang mendominasi mempengaruhi LDR adalah faktor internal, sehingga LDR tidak memiliki hubungan signifikan dengan $\mathrm{BI}$ rate.

Hasil estimasi VECM jangka pendek LDR memiliki hubungan negatif dan signifikan dengan IHK. Hal ini dikarenakan dengan ketika terjadi inflasi maka masyarakat akan cenderung lebih banyak meminjam untuk kebutuhan konsumsi, namun dalam kasus lain ketika terjadi kenaikan inflasi, bank membatasi jumlah pinjaman terhadap nasabah dikarenakan kekhawatiran terjadi nya kredit macet akibat tidak mampunya masyarakat (debitur) untuk mengembalikan atau membayar pinjaman. Sehingga dalam kasus ini jangka pendek ini diterapkannya pembuatan kebijakan membatasi pinjaman membuat LDR untuk sementara dalam meminimalisir kredit macet sehingga kinerja perbankan baik dan efisien. 


\section{Impulse response function (IRF)}

Analaisis Impulse Respose function (IRF) untuk menganalisis dampak guncangan (shock) pada IPI terhadap kinerja perbankan, shock pada IHK terhadap kinerja perbankan, dan terakhir adalah melihat shock BI rate terhadap kinerja perbankan. Sedangkan untuk variance decompotion digunakan untuk mengetahui seberapa besar kontribusi variabel IPI, IHK, dan BI rate terhadap kinerja perbankan. Hasil analisis IRF dan Variance Decomposition selengkapnya terlampir pada lampiran. Analisis IRF digunakan untuk menunjukan bagaimana respon suatu variabel dari sebuah shock dalam variabel itu sendiri dan variabel endogen lainnya.
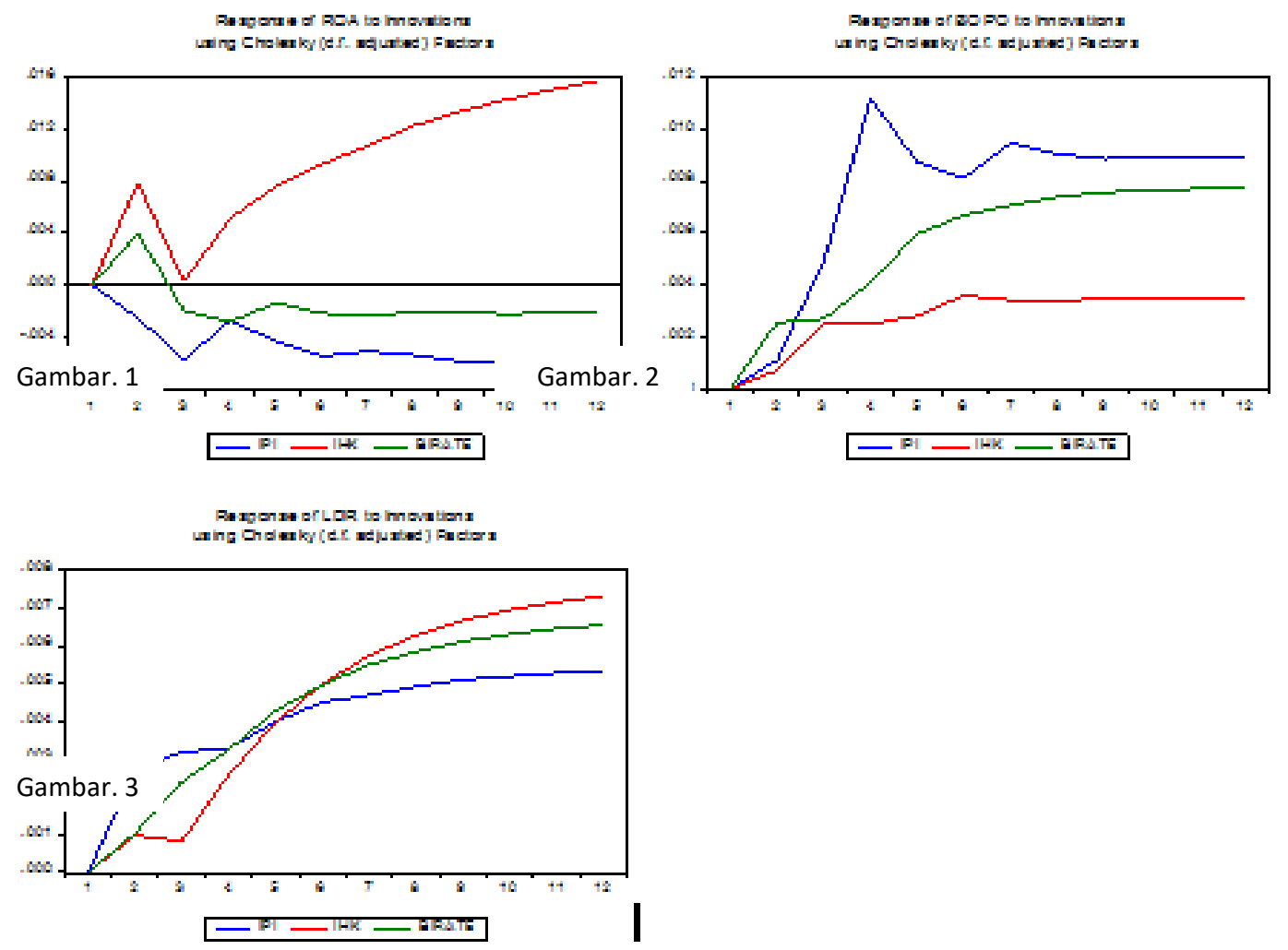

Gambar 1-3. Respon ROA, BOPO dan LDR, akibat shock dari IPI, IHK dan BI rate

Gambar 1. menunjukkan respon positif ROA terhadap guncangan IHK. IHK pada periode 1 sampai periode 12 direspon positif oleh ROA. Inflasi yang diakibatkan oleh perkembangan siklus bisnis akan menyebabkan perekonomian mengalami booming. Inflasi atau IHK yang terjadi karena hal tersebut biasanya berpengaruh lebih besar terhadap sisi penerimaan dibandingkan dari sisi biaya, dan berakhir pada kinerja bank yang baik. Pengaruh inflasi sendiri tergantung apakah inflasi tersebut sudah diantisipasi atau belum oleh pihak bank. Jika inflasi diantisipasi secara penuh, maka tingkat suku bunga yang diberlakukan bank akan meningkat untuk meng-cover risiko inflasi. Sehingga peningkatan pendapatan lebih cepat dibandingkan dengan peningkatan biaya, sehingga berdampak positif terhadap kinerja bank khususnya tingkat profitabilitas.

Selanjutnya ROA merespon negatif akibat guncangan IPI pada periode ke 3, Ketika peningkatan pendapatan nasional yang dijelaskan dengan pertumbuhan ekonomi yang semakin tinggi berasosiasi dengan semakin berkembangnya sektor perbankan 
sehingga persaingan antar satu bank dengan bank lain semakin ketat, dan akhirnya dapat menurunkan tingkat profitabilitas bank.

ROA merespon negatif akibat adanya shock dari BI rate, shock terjadi pada periode 3 . Ketika BI rate mengalami peningkatan yang berakibat suku bunga bank juga ikut meningkat akan meningkatkan pola saving pada masyarakat meningkat, ketika saving meningkat maka beban bunga simpanan akan meningkat, namun disisi lain profitabilitas bank menurun akibat beban bunga simpanan yang dibayarkan bank kepada nasabah lebih besar.

Gambar 2 menunjukkan respon positif BOPO terhadap guncangan (shock) dari IPI, IHK dan BI rate. Shock pada IPI direspon positif oleh BOPO hal tersebut dapat dilihat pada periode ke 3 dimana IPI mengalami shock tertinggi, dan hal ini dikarenakan ketika perkembangan perekonomian mengalami booming, terdapat lebih banyak sumber modal yang bisa didapat dengan mudah di pasar uang sebagai menyangga dari berbagai kemungkinan yang terjadi akibat adanya aktivitas risk taking. Selain itu ketika perekonomian tumbuh meningkat maka akan mempengaruhi pendapatan masyarakat, dengan pendapatan masyarakat yang bertambah akan membuat pola saving masyarakat di perbankan akan meningkat dan akan meningkatkan beban bunga DPK, dan beban operasional lainnya sehingga BOPO mengalami peningkatan juga.

Shock pada BI rate dan IHK direspon positif oleh BOPO. Hal ini dijelaskan pada gambar 9 dimana BI rate mengalami guncangan yang tinggi pada periode ke-4 hal ini menjelaskan ketika peningkatan BI rate akan meningkatkan pula suku bunga simpanan pada bank dan merubah pola saving masyarakat yang akan meningkatkan beban dan pihak ketiga, beban bunga operasional lainnya sehingga BOPO juga mengalami peningkatan. Selanjutnya BOPO merespon positif terhadap guncangan dari IHK pada periode ke-3, dimana ketika terjadi inflasi tetapi tidak diantisipasi penuh oleh pihak bank maka suku bunga mengalami penyesuaian yang lamban, sehingga peningkatan biaya lebih cepat dibandingkan peningkatan pendapatan, dan akhirnya inflasi berdampak negatif terhadap profitabilitas dimana indikator rasio profitabilitas diproksikan oleh BOPO.

Gambar 3 menunjukkan respon positif LDR terhadap guncangan (shock) dari IPI, IHK dan BI rate. Shock pada IPI yang terjadi dimulai dari periode 1 direspon positif oleh LDR hal ini dikarenakan akibat shock yang terjadi maka suatu bank akan membuat kebijakan dalam menyalurkan kredit dengan prinsip kehati-hatian dengan alasan pihak bank meragukan kemampuan debitur (masyarakat) dalam mengembalikan pinjaman dari bank dimana yang menjadi tolak ukur adalah capacity nya sehingga, jumlah kredit pada bank cenderung akan stagnan atau tetap. Dalam kasus ini pembuatan kebijakan ini bertujuan untuk mengurangi jumlah pinjaman pada bank, sehingga dalam kasus seperti ini LDR diasumsikan merespon positif akibat guncangan atau shock dari IPI.

LDR merespon positif akibat guncangan dari IHK, hal ini dikarenakan ketika kenaikan inflasi pada periode ke-3 akan mengakibatkan konsumsi yang dikeluarkan oleh masyarakat akan memerlukan dana yang sangat besar. Dengan kenaikan konsumsi masyarakat akan mempengaruhi saving yang dilakukan oleh masyarakat, dimana masyarakat lebih banyak meminjam uang untuk konsumsi dibandingkan menyimpan uang di bank sehingga ketika inflasi meningkat maka rasio pinjaman deposito meningkat, atau kata lain LDR merespon positif akibat adanya shock dari IHK. 
LDR merespon positif dari awal periode akibat adanya shock dari BI rate, namun periode ke-3 ketika BI rate mengalami shock maka menyebabkan suku bunga bank juga ikut merosot atau menurun, akibatnya dalam kasus ini masyarakat lebih memilih untuk meminjam uang di bank dibandingkan menyimpan uang nya, sehingga LDR meningkat seiring menurunnya suku bunga bank akibat penurunan dari BI rate itu sendiri. Dalam hal ini LDR merespon positif akibat adanya shock dari BI rate.

\section{Variance decomposition}

Variance decomposition digunakan untuk meyusun forcast error variance suatu variabel, yaitu seberapa besar perbedaan antara variance sebelum dan sesudah shock, dari variabel lain untuk melihat pengaruh relatif variabel-variabel penelitian terhadap variabel lainnnya.

Tabel 1. Hasil analisis variance decomposition (Rata-rata selama 12 bulan, dalam persen)

\begin{tabular}{lllll}
\hline Variabel & Dirinya sendiri & IPI & IHK & BI Rate \\
\hline ROA & 91.04903917 & 1.876519 & 6.447274 & 0.627169 \\
BOPO & 99.40170417 & 0.148866 & 0.237459 & 0.211972 \\
LDR & 67.14409083 & 10.95004 & 10.68565 & 11.22022 \\
\hline
\end{tabular}

Sumber : Data diolah, 2019

Berdasarkan hasil estimasi Tabel 15 menunjukkan kontribusi variabel makro (IPI, IHK, dan BI rate) terhadap kinerja bank indikator (ROA, BOPO, dan LDR). Dalam estimasi di atas dapat disimpulkan bahwa kontribusi terbesar pada variabel kinerja perbankan diperoleh dari variabel kinerja itu sendiri. Namun dari segi variabel makro yang memberikan kontribusi tertinggi pada ROA, yaitu adalah IHK dengan ratarata variance decomposition (VD) sebesar $6,44 \%$ disusul oleh variabel IPI yaitu sebesar $1,87 \%$ dan selanjutnya kontribusi terendah diperoleh dari BI rate yaitu sebesar $0,627 \%$. Selanjutnya variabel makro yang memberikan kontribusi tertinggi pada BOPO adalah IHK dengan rata-rata variance decomposition (VD) sebesar 0,23\%, disusul oleh variabel BI rate dengan rata-rata VD yaitu sebesar $0,21 \%$, dan yang terakhir yaitu IPI dengan VD sebesar $0,14 \%$. Selanjutnya variabel makro yang memberikan kontribusi terbesar oleh variabel LDR adalah BI rate dengan variance decomposition (VD) sebesar $11,22 \%$, dan kontribusi yang kedua yaitu diperoleh dari IPI dengan variance decomposition (VD) sebesar 10,95\%, dan yang terakhir kontribusi LDR diperoleh dari variabel IHK dengan variance decomposition sebesar 10,68\%.

\section{KESIMPULAN DAN SARAN}

\section{Kesimpulan}

Berdasarkan hasil estimasi VECM jangka panjang variabel ROA memiliki hubungan positif dan signifikan dengan IPI dan ROA memiliki hubungan negatif dan signifikan dengan IHK dengan tingkat kepercayaan 99 persen. Hasil estimasi VECM jangka panjang variabel BOPO memiliki hubungan negatif dan signifikan dengan IPI dengan tingkat kepercayaan 99 persen, sedangkan hasil estimasi VECM jangka panjang 
variabel LDR memiliki hubungan negatif dan signifikan dengan variabel IPI, IHK dan $\mathrm{BI}$ rate dengan tingkat kepercayaan 99 persen.

Berdasarkan hasil estimasi VECM jangka pendek variabel ROA memiliki hubungan negatif dan signifikan dengan variabel IHK dan BI rate dengan tingkat kepercayaan 95 persen dan 99 persen. Hasil estimasi VECM jangka pendek variabel BOPO memiliki hubungan negatif dan signifikan dengan variabel IPI, sedangkan untuk estimasi VECM jangka pendek variabel LDR memiliki hubungan negatif dan signifikan dengan IHK.

Berdasarkan hasil Impulse Respons Function (IRF), ROA merespon positif akibat adanya guncangan dari IHK, dan ROA merespon negatif akibat adanya guncangan dari IPI, dan BI rate. Berdasarkan hasil Impulse Respons Function (IRF), BOPO merespon positif akibat adanya guncangan dari IPI, IHK, dan BI rate. Berdasarkan hasil Impulse Respons Function (IRF), LDR merespon positif akibat adanya guncangan dari IPI, IHK, dan BI rate. Kontribusi terbesar pada indikator ROA diperoleh dari variabel IHK, sedangkan kontribusi terbesar pada indikator BOPO diperoleh oleh variabel IHK. Dan yang terakhir kontribusi terbesar pada indikator LDR diperoleh oleh BI rate.

Implikasi Kebijakan untuk Keberhasilan perbankan dalam mencapai profitabilitas dapat menumbuhkan rasa kepercayaan masyarakat. Kondisi makroekonomi memberikan sinyalemen dan tanda bagi perbankan untuk segera mengambil sikap agar tujuan dari pembentukan profitabilitas yang tinggi dapat dijaga.

\section{Saran}

Hal ini perlu diperhatikan secara mendalam dan berikut saran yang dapat direkomendasikan, yakni pemerintah dan bank sentral perlu memiliki skema kebijakan yang bertujuan untuk mengontrol jalannya sistem kinerja perbankan agar tetap dalam on the track, diperlukannya perluasan kajian mengenai makroprudensial dalam hal riset dan penelitian dengan model yang lebih inovatif, variabel yang lebih banyak dan simpel yang lebih luas lagi.

\section{DAFTAR PUSTAKA}

Akani, H. W., Nwanna, I., \& Mbachu, A. (2016). Effects of selected macroeconomic variables on commercial banks performance in Nigeria. International journal of banking and finance research, 2(3), 34-75.

Aviliani, A., Siregar, H., Maulana, T. N. A., \& Hasanah, H. (2015). The impact of macroeconomic condition on the banks performance in Indonesia. Buletin ekonomi moneter dan perbankan, 17(4), 379-402.

Bank Indonesia. (2011). Peraturan bank indonesi nomor 13/1/pbi/2011 tentang penilaian tingkat kesehatan bank umum. Bank Indonesia: Jakarta.

Gerlach, S., Peng, W., \& Shu, C. (2005). Macroeconomic conditions and banking performance in Hong Kong SAR: A panel data study. BIS Papers, 22(2), 481497.

Gizycki, M. C., \& Gizycki, M. (2001). The effect of macroeconomic conditions on banks' risk and profitability. Reserve bank of Australia.

Kasmir. (2012). Dasar-dasar Perbankan. Rajawali Pers: Jakarta.

Kasmir. (2014). Manajemen perbankan edisi revisi. Raja Grafindo Persada: Jakarta.

Mankiw, N.Gregory, dkk. (2010). Pengantar ekonomi makro. Salemba Empat: Jakarta. 
Mishkin, Frederic S. (2008). Ekonomi uang, perbankan, dan pasar keuangan. 8th. Salemba Empat: Jakarta.

Otoritas Jasa Keuangan. (2012). Laporan capaian kinerja bank. Otoritas Jasa Keuangan: Jakarta.

Shu, C. (2002). The impact of macroeconomic environment on the asset quality of Hong Kong's banking sector. Hong Kong Monetary Authority Research Memorandums, 2002, 1-26.

Siregar, Hermanto. (2015). The impact makroeconomic condition on the bank's performance in Indonesia. Buletin ekonomi moneter dan perbankan. April. 380401. 